\title{
Mother-child HIV-1 transmission in the departments of Mono and Couffo in Benin: incidence and associated factors in 2019
}

Hornel Koudokpon

Universite d'Abomey-Calavi

Victorien Dougnon ( $\square$ victorien88@hotmail.com )

University of Abomey-Calavi https://orcid.org/0000-0001-9047-7299

Sètondji Islamiath Kissira

Universite d'Abomey-Calavi

Jean-Pierre Gnimatin

Universite d'Abomey-Calavi

Alida Oussou

Universite d'Abomey-Calavi

Reine Tossa

Universite d'Abomey-Calavi

Gilbert Degbelo

Universite d'Abomey-Calavi

Lamine Baba-Moussa

Universite d'Abomey-Calavi

Clément Ahoussinou

Universite d'Abomey-Calavi

Research article

Keywords: HIV1, HIV-positive mothers, newborns, associated factors

Posted Date: August 12th, 2020

DOl: https://doi.org/10.21203/rs.3.rs-53436/v1

License: (c) (i) This work is licensed under a Creative Commons Attribution 4.0 International License.

Read Full License 


\section{Abstract}

Background: Despite worldwide success of introducing HIV testing and treatment with antiretroviral drugs, HIV remains a real public health problem. Vertical mother-child transmission is a form responsible for many cases of new infections. This study was therefore carried out in order to reduce the prevalence of mother-to-child transmission of HIV-1 in the departments of Mono and Couffo.

Method: For this purpose, a total of 374 dry blood spots (DBS) were collected from infants born to HIVpositive mothers during the year 2019, and these DBS were used for the molecular diagnosis of HIV1 in these infants. Information on the type of treatment, the type of diet of infants was also collected. The viral loads of the mothers before delivery were determined after the last antenatal visits. To do so, a venous blood sample was taken from an EDTA tube. These different samples were used for DNA extraction. The early diagnosis of these infants as well as the determination of the viral load were carried out by RT-PCR using the Roche automated system. The results were analyzed with the chi-square test on the SPSS software.

Result: The results showed that $51 \%$ of the newborns included in the study were male and the vast majority of the newborns were in the 0-6 month age group. $93.41 \%$ of the newborns included in this study were tested negative for early detection by RT-PCR. Significant links were observed between the early diagnosis of newborns and the mother's mode of feeding, the PMTCT protocol, and the viral load of the mothers. Monoprophylaxis was predominant in the newborn PMTCT protocol (96.28\%).

Conclusion: The national program for the prevention of vertical transmission of HIV from mother to child deserves to be continued and strengthened with the objective of zero newborns infected at birth in the departments of Mono and Couffo.

\section{Background}

HIV has been present since 1981 and despite the worldwide success of introducing diagnostic tests and treating HIV with antiretroviral drugs, it remains a real challenge for humanity, especially as no preventive treatment has been further developed [1]. In sub-Saharan Africa, about $60 \%$ of HIV infections in young adults occur in women. This gender disparity is particularly pronounced among adolescents and young adults, where the incidence of HIV in women is up to eight times higher than in men [2]. This poses a real challenge in that women play a very indispensable role in procreation by carrying a pregnancy. Transmission of HIV from HIV-positive mothers to newborns can occur during pregnancy or through breastfeeding [3, 4]. In fact, more than 36 million people were living with the virus in 2015, including more than 2 million newly infected [1]. These figures include 1.8 million infants infected with HIV, the majority of whom acquired the virus through mother-to-child transmission of HIV [1]. In order to fight against this form of transmission, Benin has set up a national program for the prevention of mother-to-child transmission (PMTCT) since 2004. Every pregnant woman is systematically offered, during prenatal consultations, an HIV test after an HIV test. counseling session and free and informed consent according 
to the recommendations of UNAIDS and WHO [5]. Benin has twelve (12) departments and among them, those in which the largest number of cases of HIV infection are recorded are Mono (2.1\%) and Couffo $(2.2 \%)$ (Ministry of Health Benin, 2018). We therefore focused on the quality of PMTCT in these departments in order to identify billers associated with mother-to-child transmission of HIV1 in these departments. This study was therefore conducted with the aim of determining the incidence of vertical mother-to-child transmission of HIV in the departments of Mono and Couffo in order to contribute to the reduction of mother-to-child HIV prevention in these areas. departments.

\section{Methods}

\section{Study design}

The present study covered the whole of the Mono and Couffo departments. It was a cross-sectional, prospective and descriptive study carried out by taking into account all infants born from HIV-positive mothers in these two departments during the year 2019. Manipulations took place at CIPEC Mono Couffo located in LOKOSSA commune. The sampling method was exhaustive and systematic among all infants born from HIV-positive mothers who presented at the PMTCT care centers in these two departments.

\section{Sampling}

The biological materials in the present study consist of DBS samples obtained from the heel or atrial fingertip of infants born to HIV-positive mothers and EDTA blood samples from mothers that were used for viral load testing.

\section{Dna Extraction}

DNA extraction was performed according to the manufacturer's recommendations for the kit abbott msample preparation system (Abbott, Chicago, United State). Two spots of the DBS are first cut out of a $50 \mathrm{ml}$ Falcon tube. Then $1.4 \mathrm{ml}$ of lysis solution and magnetic beads are added. The mixture is stirred for $20 \mathrm{~min} .1 \mathrm{ml}$ of the mixture is then transferred to a $5 \mathrm{ml}$ tube to which $2.4 \mathrm{ml}$ of lysis solution and $40 \mu \mathrm{l}$ of microparticles are added. After stirring for $20 \mathrm{~min}, 1 \mathrm{ml}$ of the mixture is placed in an Eppendorf tube and placed in a magnetic rack followed by two washing turns. The mixture is incubated at $75^{\circ} \mathrm{C}$ to allow vaporization. $88 \mu$ l elution buffer is added and the supernatant is transferred to an Eppendorf tube. For blood samples on EDTA the procedure was the same.

\section{Early HIV-1 Diagnosis Among Infants}

The early diagnosis of HIV-1 in newborns was carried out by RT-PCR according to the recommendations of the COBAS Ampliprep / COBAS Taqman CAP / CTM system version2.0 qualitative of the Roche range 
(Roche Diagnostics Ltd, Rotkruez, Switzerland). This target system targeting both the HIV-1 gag p24 gene and the LTR region. $1000 \mu \mathrm{l}$ of specimens and controls were used using the HI2QLD48 program [6, 7].

\section{Detection Of Viral Charge In HIV-positive Pregnant Women}

The same procedure was used for the detection of the viral load of women with this time the quantitative kit. the HI2CAP48 program was used [8, 9].

\section{Statistical Analysis}

The results were analyzed with the SPSS software. For the Chi-square test, the difference is considered to be significantly positive for a value less than or equal to 0.05 .

\section{Results}

This study was therefore conducted in order to reduce the prevalence of mother-child HIV- 1 transmission in the departments of Mono and Couffo. Analysis of the distribution of infants included in this study by sex shows a male predominance in a low average (Fig. 1). The age distribution of these infants shows a high representation of infants in the 0 to 6 months age group with a percentage of $86 \%$ (Fig. 2). There was also repair according to the feeding mode and the weaning period. The majority of these infants were fed through protected breastfeeding $(57.59 \%)$ and $98.85 \%$ of these infants were not yet weaned by more than 1 year of age and $1 / 2$ (Figs. 3 and 4 ). The sampling method was exhaustive and systematic among all infants born from HIV-positive mothers received at PMTCT care centers in the Mono and Couffo departments. Investigation of the PMTCT protocol showed that the two most predominant were triple therapy before pregnancy and triple therapy during pregnancy, with percentages of $37.25 \%$ and $35.53 \%$ respectively (Fig. 5). With regard to the PMTCT protocol for newborns, monoprophylaxis is predominant with a percentage of $96.28 \%$ (Fig. 6). This study was also conducted to explore the link between viral load in mothers and the contamination of their infants. Thus, the PCR performed for early diagnosis yielded a very low positivity rate (6.59\%). It should be noted that $52.2 \%$ of PCRs performed in female newborns are positive, while the positivity rate in male infants is $51.2 \%$ (Table 1). There is an insignificant difference between the rate of positivity and the rate of negativity according to sex. PCR results for infants according to feeding mode show that among those with a positive result, the majority follow breastfeeding (65.2\%). Thus, there is a significant difference in the PCR results by feeding mode (Table 2). The distribution of PCR results for infants according to weaning age. We note that the PCR gave a positive result in all infants who have not yet been weaned. The difference in PCR results by weaning age was not significant (Table 3). The PCR results for newborns according to the mother's PMTCT protocol show that the high positivity rate was observed in mothers not following any PMTCT protocol. There is a significant difference between the PCR results according to the maternal PMTCT protocol (Table 4). With regard to the results of the PCR based on the PMTCT protocol for infants, the highest positivity rate was found in infants following monoprophylaxis (91.3\%) (Table 5). 
Table 1

Distribution of newborn PCR results by gender

\begin{tabular}{|c|c|c|c|c|}
\hline \multirow[t]{2}{*}{ Sex } & \multicolumn{2}{|l|}{ PCR Result } & \multirow[t]{2}{*}{ Total } & \multirow[t]{2}{*}{ khi-deux test } \\
\hline & Negative & Positive & & \\
\hline Female & $159(48,8 \%)$ & $12(52,2 \%)$ & 171 (49\%) & \multirow[t]{3}{*}{0,460} \\
\hline Male & $167(51,2 \%)$ & $11(47,8 \%)$ & 178 (51\%) & \\
\hline Total & $326(100 \%)$ & $23(100 \%)$ & 349 (100\%) & \\
\hline
\end{tabular}

Table 2

Distribution of newborn PCR results by feeding mode

\begin{tabular}{|c|c|c|c|c|}
\hline \multirow[t]{2}{*}{ Mode d'alimentation } & \multicolumn{2}{|l|}{ PCR Result } & \multirow[t]{2}{*}{ Total } & \multirow[t]{2}{*}{ khi-deux test } \\
\hline & Negative & Positive & & \\
\hline Substitute foods & $7(2,1 \%)$ & $0(0 \%)$ & $7(2 \%)$ & \multirow[t]{5}{*}{0,0004} \\
\hline Breastfeeding & $121(37,1 \%)$ & $15(65,2 \%)$ & $136(39 \%)$ & \\
\hline Protected breastfeeding & $195(59,8 \%)$ & $6(26,2 \%)$ & $201(57,6 \%)$ & \\
\hline Mixed feeding & $3(0,9 \%)$ & $2(8,7 \%)$ & $5(1,4 \%)$ & \\
\hline Total & $326(100 \%)$ & $23(100 \%)$ & 349 (100\%) & \\
\hline
\end{tabular}

Table 3

Newborn PCR results by weaning date

\begin{tabular}{|c|c|c|c|c|}
\hline \multirow[t]{2}{*}{ Weaning date } & \multicolumn{2}{|l|}{ PCR Result } & \multirow[t]{2}{*}{ Total } & \multirow[t]{2}{*}{ khi-deux Test } \\
\hline & Negative & Positive & & \\
\hline 1 year & $2(0,6 \%)$ & $0(0 \%)$ & $2(0,6 \%)$ & \multirow[t]{5}{*}{0,963} \\
\hline 10 months & $1(0,3 \%)$ & $0(0 \%)$ & $1(0,3 \%)$ & \\
\hline 1 year $1 / 2$ & $1(0,3 \%)$ & $0(0 \%)$ & $1(0,3 \%)$ & \\
\hline Not yet & $322(98,8 \%)$ & $23(100 \%)$ & $345(98,9 \%)$ & \\
\hline Total & $326(100 \%)$ & 23 (100\%) & 349 (100\%) & \\
\hline
\end{tabular}


Table 4

Distribution of PCR results in newborns by maternal PMTCT protocol

\begin{tabular}{|c|c|c|c|c|}
\hline \multirow[t]{2}{*}{ Mother's PMTCT Protocol } & \multicolumn{2}{|l|}{ PCR Result } & \multirow[t]{2}{*}{ Total } & \multirow[t]{2}{*}{ khi-deux Test } \\
\hline & Negative & Positive & & \\
\hline None & $49(15 \%)$ & $12(52,2 \%)$ & $61(1,5 \%)$ & \multirow[t]{6}{*}{0,0003} \\
\hline Monoprophylaxis & $9(2,8 \%)$ & $0(0 \%)$ & $9(2,6 \%)$ & \\
\hline Triprophylaxis & $24(7,4 \%)$ & $1(4,3 \%)$ & $25(7,2 \%)$ & \\
\hline Tritherapy during pregnancy & $120(36,8 \%)$ & $4(17,4 \%)$ & $124(35,5 \%)$ & \\
\hline Tritherapy before pregnancy & $124(38 \%)$ & $6(26,1 \%)$ & $130(37,2 \%)$ & \\
\hline Total & $326(100 \%)$ & $23(100 \%)$ & 349 (100\%) & \\
\hline
\end{tabular}

Table 5

Distribution of newborn PCR results according to the newborn PMTCT protocol

\begin{tabular}{|c|c|c|c|c|}
\hline \multirow[t]{2}{*}{ PMTCT Protocol for Children } & \multicolumn{2}{|l|}{ PCR Result } & \multirow[t]{2}{*}{ Total } & \multirow[t]{2}{*}{ khi-deux Test } \\
\hline & Negative & Positive & & \\
\hline N6one & $10(3,1 \%)$ & $2(8,7 \%)$ & $12(3,4 \%)$ & 0,348 \\
\hline Monoprophylaxis & $315(96,6 \%)$ & $21(91,3 \%)$ & $336(96,3 \%)$ & \\
\hline Triprophylaxis & $1(0,3 \%)$ & $0(0 \%)$ & $1(0,3 \%)$ & \\
\hline Total & $326(100 \%)$ & 23 (100\%) & 349 (100\%) & \\
\hline
\end{tabular}

\section{Discussion}

the HIV pandemic continues to cause a heavy burden in large populations such as those in the Mono Couffo departments in Benin. reducing the transmission of the virus continues to be at the heart of many actions at the national and international level. In Benin, the PMTCT Program, which aims to reduce vertical mother-to-child transmission, has been in place since 2004, but there are still cases of children born from seropositive mothers with HIV. This study therefore sought to identify the factors that influence this transmission in the departments of Mono and Couffo where the highest rates of HIV infection in Benin are recorded. Early detection of newborns by RT-PCR gave a positivity rate of $6.59 \%$. This rate, although low, poses the problem of the full implementation of the national program for the prevention of mother-to-child transmission of HIV. it is far higher than the rate reported in developed countries such as the United Kingdoms (less than $2 \%$ from 200-2006) [10]. the same is true for many other developed countries [11]. African countries such as the Ivory Coast [12], Cameroon [13], Mali [14], Malawi [15], South Africa [16], Zambia [17] and Ethiopia [18], Schumann at al., [19] have also had to obtain very low rates of MTCT. some countries have even reported having completely eliminated mother-to-child transmission of the virus $[20,21]$. 
Indeed, many studies have reported the existence of several factors that can lead to the absence of opportunities for the prevention of vertical transmission of HIV such as the lack of knowledge of the population on the prevention of mother-to-child transmission of HIV, the antenatal service system and the HIV testing capacity of institutions, the monitoring method all correlated with underdevelopment [22].

The vast majority ( $86 \%$ ) of the newborns included in this study were between 0 and 6 months old. This rate, close to national statistics, which gives $79.9 \%$ of screening in the first half of 2015 , shows commendable efforts by the government to reduce the incidence of mother-to-child transmission of HIV by providing CIPECs with equipment for this diagnosis and the review. the plan to eliminate mother-tochild transmission of HIV [23]. This report also highlighted the gaps in the diagnosis which is justified by cases of children screened between 6 and 24 months. According to some authors, the socio-economic level of mothers, the low level of education and the non-involvement of the co-progenitor can constitute real obstacles $[16,24,25]$.

the study of factors related to mother-to-child transmission of HIV shows a statistical association of mother-to-child transmission of HIV-1 with factors such as mother's PMTCT protocol, method of breastfeeding newborns, and the last viral load of mothers in the departments of Mono-Couffo in 2019.

Since 2004, a program to prevent mother-to-child transmission of HIV has been implemented nationwide in Benin. This study explored the correlation between the viral load of mothers and HIV transmission to newborns in the Mono and Couffo departments where the highest rates of HIV infection in Benin are recorded. Early screening of newborns by PCR gave a positivity rate of $6.59 \%$. This rate, although low, raises the problem of full implementation of the national program for the Prevention of Mother-Child Transmission of HIV. Indeed, many studies have reported the existence of several factors that may result in the absence of opportunities for the prevention of vertical transmission of HIV such as the lack of knowledge of the population on the prevention of mother-to-child transmission of HIV, the system of antenatal services and the HIV testing capacity of the institutions, the mode of follow-up [22].

the studies by Kassaw et al. [18], Mandelbrot et al. [26] have already shown the effectiveness of WHO option B, which recommends the administration of antiretroviral treatment to all HIV-positive pregnant and breastfeeding women, regardless of CD4 cell count or clinical stage. however, in some regions of the world, such as the rural areas considered in this study, the effectiveness of the prenatal consultations recommended by the WHO is still a problem. Women lacking in means are unable to make antenatal consultations with no knowledge of serological status. Numerous studies have also highlighted the role of breastfeeding in the mother-to-child transmission of HIV1 $[27,28]$ and that of the role of neonatal and child prophylaxis [29]. Regarding the method of breastfeeding, social factors such as knowledge of the serological status by the husband or the in-laws play an enormous role in the choice of the method of breastfeeding despite medical advice, especially in rural areas [30]. It is also necessary to take into account the rural environment which, according to the WHO, influences compliance with PMTCT recommendations [4]. The studies by Saizonou et al. [31] showed, for example, a good score for compliance with PMTCT in Cotonou, the economic capital of Benin [32] (WHO, 2011). 
It is therefore important to further strengthen current strategies in order to increase adherence of HIVpositive women to PMTCT guidelines. The study by Tudor et al. describes, for example, that integrated PMTCT services could effectively reduce mother-to-child transmission of HIV [33]. Ibeziako et al. have shown that holistic but cost-effective prevention interventions help reduce the rate of mother-to-child transmission of HIV, even in economically developing countries [34]. These measures will achieve a reduction or even eradication of mother-to-child transmission of HIV [35].

\section{Conclusion}

In pregnant women, routine screening is crucial to prevent any vertical transmission of HIV. In this study covering two of Benin's twelve departments, it emerged that this protocol is truly effective for this prevention. However, studies still need to be conducted in the other departments of Benin in order to get a true picture of the situation. The existent preventing program has been in place since 2004; we should therefore think about monitoring this program while following the Deming wheel (Plan-Do-Check-Act) for a continuous improvement of its effectiveness.

\section{Abbreviations}

HIV: Human immunodeficiency virus

HIV-1: Human immunodeficiency virus 1

EDTA: Ethylenediaminetetraacetic acid

DNA: Deoxyribonucleic acid

PMTCT: Prevention of Mother To Children Transmission

CIPEC: Center for information, foresight and advice

PCR: Polymerase Chain Reaction

RT-PCR: Reverse transcription polymerase chain reaction

\section{Declarations}

\section{Ethics Approval and Consent to Participate}

The Benin National Ethical Committee for Health Research has reviewed and approved this study under No 65/MS/DC/SGM/DRFMT/CNERS/SA. A written approval was taken from each patient involved in the study. Consent to participate was obtained from the parents or guardians of the infants included in this study. 
All authors have read and gave their consent for publication. Written informed consent was obtained from the patients for publication of their individual details and accompanying images in this manuscript. However, the data submitted for this publication cannot permit to reveal their identity. The consent form is held by the authors' institution (Polytechnic School of Abomey-Calavi) and is available for review by the Editor-in-Chief.

\section{Availability of data and material}

The datasets used and/or analyzed during the current study are available from the corresponding author upon reasonable request.

\section{Competing interests}

The authors declare there is no conflict of interest related to this publication.

\section{Funding}

This study was self-funded. The authors also thank Drs Jerrold AGBANKPE and Esther DEGUENON for their technical support. They help for the setting up of the study and analyzing the results. They are grateful to the whole staff from the Research unit in Applied Microbiology and Pharmacology of natural substances (University of Abomey-Calavi, Benin).

\section{Author Contributions}

HK, VD, SIK, J-P G and CA drafted the protocol and supervised the study.

$H K, A O, R T, G D$ and VD did the statistical analyses.

HK and J-P G wrote the draft of the manuscript.

VD, HK, and CA reviewed the manuscript.

All authors have read and approved the manuscript

\section{Acknowledgments}

The authors thank the staff involved in the study.

\section{References}

1. UNAIDS. AIDS by the numbers, AIDS is not over, but it can be. Genève; 2016 .

2. Kharsany ABM, Karim QA. HIV Infection and AIDS in Sub-Saharan Africa: Current Status, Challenges and Opportunities. Open AIDS J. 2016;10:34-48. doi:10.2174/1874613601610010034. 
3. Potty RS, Sinha A, Sethumadhavan R, Isac S, Washington R. Incidence, prevalence and associated factors of mother-to-child transmission of HIV, among children exposed to maternal HIV, in Belgaum district, Karnataka, India. BMC Public Heal. 2019;19:10p. doi:10.1186/s12889-019-6707-3.

4. Frange P, Blanche S. VIH et transmission mère-enfant. Press Medicale. 2014;43:691-7.

5. Kêdoté NM, Brousselle $A$, Champagne $F$, Laudy D. Prévention de la transmission mère-enfant du $\mathrm{VIH} /$ sida au Bénin: le consentement des femmes au dépistage est-il libre et éclairé? Ethique et Sante. 2011;8:173-9.

6. Gueye SB, Diop-Ndiaye H, Diallo MM, Ly O, Sow-Ndoye A, Diagne-Gueye ND, et al. Performance of Roche CAP/CTM HIV-1 qualitative test version 2.0 using dried blood spots for early infant diagnosis. J Virol Methods. 2016;229:12-5. doi:10.1016/j.jviromet.2015.12.006.

7. Shin $\mathrm{K}-\mathrm{H}$, Lee H-J, Lee JH, Chang CL. Comparison of the cobas Human Immunodeficiency Virus 1 (HIV-1) Test Using the cobas 4800 System With COBAS AmpliPrep/COBAS TaqMan HIV-1 Test and Abbott RealTime HIV-1 Assay and Performance Evaluation of cobas HIV-1. . Am J Clin Pathol . 2019;152:558-62. https://sci-hub.tw/https://doi.org/10.1093/ajcp/aqz075. Accessed 26 Jul 2020.

8. Avettand-Fénoël V, Mélard A, Gueudin M, Maillard A, Dina J, Gousset M, et al. Comparative performance of the Biocentric Generic Viral Load, Roche CAP/CTM v1.5, Roche CAP/CTM v2.0 and m2000 Abbott assays for quantifying HIV-1 B and non-B strains: Underestimation of some CRF02 strains. J Clin Virol. 2019;110:36-41. doi:10.1016/j.jcv.2018.12.002.

9. Wojewoda CM, Spahlinger T, Harmon ML, Schnellinger B, Li Q, Dejelo C, et al. Comparison of Roche Cobas AmpliPrep/Cobas TaqMan HIV-1 test version 2.0 (CAP/CTM v2.0) with other real-time PCR assays in HIV-1 monitoring and follow-up of low-level viral loads. J Virol Methods. 2013;187:1-5. doi:10.1016/j.jviromet.2012.10.004.

10. Townsend CL, Cortina-Borja M, Peckham CS, De Ruiter A, Lyall H, Tookey PA. Low rates of mother-tochild transmission of HIV following effective pregnancy interventions in the United Kingdom and Ireland, 2000-2006. AIDS. 2008;22:973-81. doi:10.1097/QAD.0b013e3282f9b67a.

11. Frange $P$, Blanche $S$, Chaix M-L. Infection de l'enfant par le VIH dans les pays industrialisés État des lieux et enjeux futurs. Médecine/Sciences. 2014;30:551-8.

12. Lasme-Guillao BE, Sissoko $M$, Guié $P$, Amon-Tanoh-Dick F. Transmission mère-enfant du VIH à Abidjan: surmonter les obstacles socio-culturels. Med Afr Noire. 2011;58:395-403.

13. Tsingaing KJ, Egbe OT, Ekane GH, Nguefack CT, Njamen TN, Imandy G, et al. Prévalence du VIH chez la Femme Enceinte et Transmission Mère-Enfant du VIH à la Maternité de l'Hôpital Général de Douala, Cameroun. Clin Mother Child Heal. 2011;8:3p.

14. Traore Y, Dicko F, Traore F, Teguete I, Mounkoro N, Thera A, et al. [Prevention of mother to child HIV transmission in an African hospital, Bamako-Mali] - PubMed. Mali Med. 2011;26:18-22. https://pubmed.ncbi.nlm.nih.gov/22766239/. Accessed 26 Jul 2020.

15. Kim MH, Ahmed S, Preidis GA, Abrams EJ, Hosseinipour MC, Giordano TP, et al. Low Rates of Motherto-Child HIV Transmission in a Routine Programmatic Setting in Lilongwe, Malawi. PLoS One. 2013;8:e64979. doi:10.1371/journal.pone.0064979. 
16. Mnyani CN, Simango A, Murphy J, Chersich M, Mcintyre JA. Patient factors to target for elimination of mother-to-child transmission of HIV. Global Health. 2014;10:7p. doi:10.1186/1744-8603-10-36.

17. Chibwesha CJ, Giganti MJ, Putta N, Chintu N, Mulindwa J, Dorton BJ, et al. Optimal Time on HAART for Prevention of Mother-to-Child Transmission of HIV. J Acquir Immune Defic Syndr. 2011;58:224-8.

18. Kassaw MW, Mamo Abebe A, Beletew Abate B, Tlaye G, Kassie M. Mother-to-child HIV transmission and its associations among exposed infants after Option $B+$ guidelines implementation in the Amhara regional state referral hospitals, Ethiopia. Int J Infect Dis. 2020;95:268-75. doi:10.1016/j.ijid.2020.03.006.

19. Schumann H, Rubagumya K, Rubaihayo J, Harms G, Wanyenze RK, Theuring S. The incidence of HIV and associated risk factors among pregnant women in Kabarole District, Uganda. PLoS One. 2020;15:1-17. doi:10.1371/journal.pone.0234174.

20. WHO. Thailand, Belarus and Armenia eliminate mother-to-child transmission of HIV. World Heal Organ. 2016. http://www.who.int/hiv/mediacentre/news/emtct-validation-2016/en/. Accessed 26 Jul 2020.

21. WHO. Malaysia eliminates mother-to-child transmission of HIV and syphilis. World Health Organisation. 2018. http://www.who.int/hiv/mediacentre/news/mtct-elimination-malaysia/en/. Accessed 26 Jul 2020.

22. Peltzer K, Sikwane E, Majaja M. Factors associated with short-course antiretroviral prophylaxis (dual therapy) adherence for PMTCT in Nkangala district, South Africa. Acta Paediatr. 2011;100:1253-7. doi:10.1111/j.1651-2227.2011.02253.x.

23. CNLS. Rapport de suivi de la déclaration de politique sur le VIH et le SIDA au Bénin 2016. Benin; 2016.

24. Morfaw F, Mbuagbaw L, Thabane L, Rodrigues C, Wunderlich A-P, Nana P, et al. Male involvement in prevention programs of mother to child transmission of HIV: a systematic review to identify barriers and facilitators. Syst Rev. 2013;2:13p. doi:10.1186/2046-4053-2-5.

25. Tshikwej Ngwej D, Mukuku O, Mudekereza R, Karaj E, Bwana Fwamba Odimba E, Numbi Luboya O, et al. Etude de facteurs de risque de la transmission du VIH de la mère à l'enfant dans la stratégie «option A» à Lubumbashi, République Démocratique du Congo. PanAfrican Med J. 2015;22:16p. doi:10.11604/pamj.2015.22.18.7480.

26. Mandelbrot L, Tubiana R, Le Chenadec J, Dollfus C, Faye A, Pannier E, et al. No perinatal HIV-1 transmission from women with effective antiretroviral therapy starting before conception. Clin Infect Dis. 2015;61:1715-25.

27. Operto E. Knowledge, attitudes, and practices regarding exclusive breastfeeding among HIV-positive mothers in Uganda: A qualitative study. Int J Health Plann Manage. 2020;35:888-96. doi:10.1002/hpm.2966.

28. Moseholm E, Weis N. Women living with HIV in high-income settings and breastfeeding. J Intern Med. 2020;287:19-31. doi:10.1111/joim.12986. 
29. Hurst SA, Appelgren KE, Kourtis AP. Prevention of mother-to-child transmission of HIV Type 1: The role of neonatal and infant prophylaxis. Expert Rev Anti Infect Ther. 2015;13:169-81.

30. Bonvalet P. Allaitement et VIH en Afrique subsaharienne : la difficile mise en oeuvre d'une politique de santé viable. Santé Int. 2011;30:399-406. https://www.cairn.info/sante-internationale-9782724611724-page-399.htm?contenu=article. Accessed 26 Jul 2020.

31. Saizonou J, Kpozèhouen A, Paraiso NM, Aguèmon B, Yahaya A, Ouédraogo L. La qualité de suivi du couple mère-enfant inclus dans le programme prévention transmission mère-enfant au Bénin. Rev Epidemiol Sante Publique. 2014;62:S243.

32. WHO. Alimentation des nourrissons dans un contexte de VIH. Geneva: World Health Organization; 2012.

33. Car LT, Van Velthoven MHMMT, Brusamento S, Car J, Majeed A, Tugwell P, et al. Integrating Prevention of Mother-to-Child HIV Transmission Programs to Improve Uptake: A Systematic Review. PLoS One. 2012;7:e35268. doi:10.1371/journal.pone.0035268.

34. Ibeziako NS, Ubesie AC, Emodi IJ, Ayuk AC, lloh KK, Ikefuna AN. Mother-to-child transmission of HIV: the pre-rapid advice experience of the university of Nigeria teaching hospital Ituku/Ozalla, Enugu, South-east Nigeria. BMC Res Note. 2012;5:6p. doi:10.1186/1756-0500-5-305.

35. Darak S, Panditrao M, Parchure R, Kulkarni V, Kulkarni S, Janssen F. Systematic review of public health research on prevention of mother-to-child transmission of HIV in India with focus on provision and utilization of cascade of PMTCT services. BMC Public Health. 2012;12:15p. http://www.biomedcentral.com/1471-2458/12/320. Accessed 26 Jul 2020.

\section{Figures}




\section{Sex}

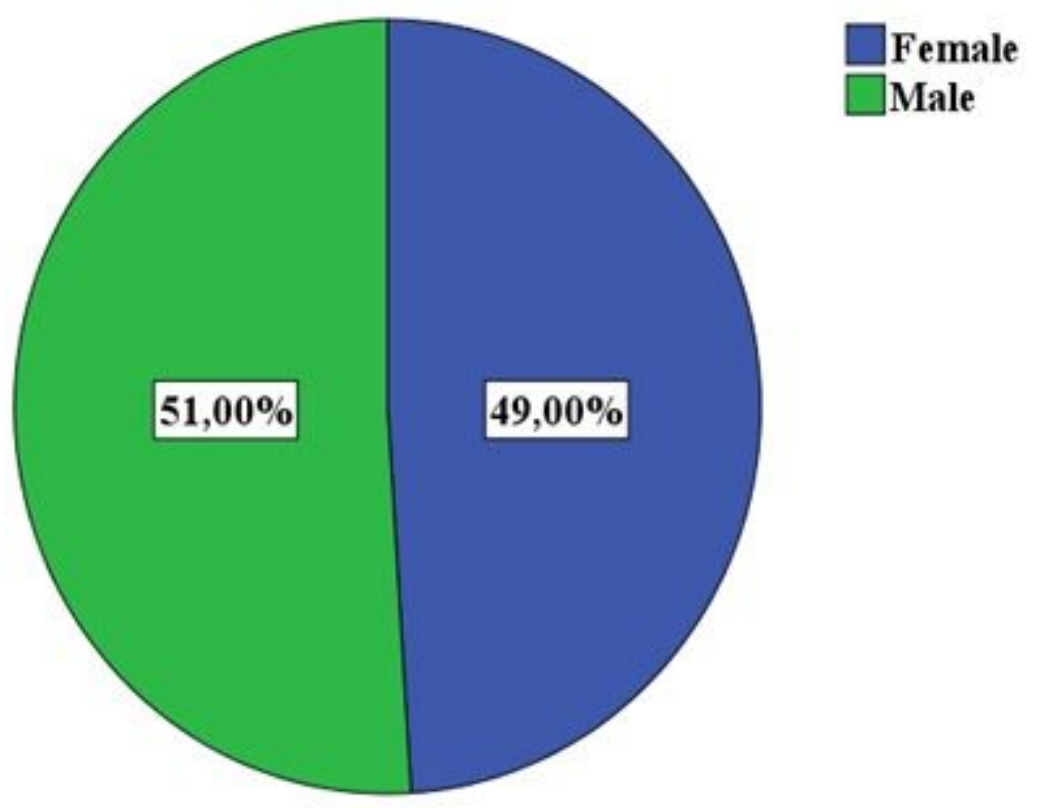

\section{Figure 1}

Distribution of infants by gender

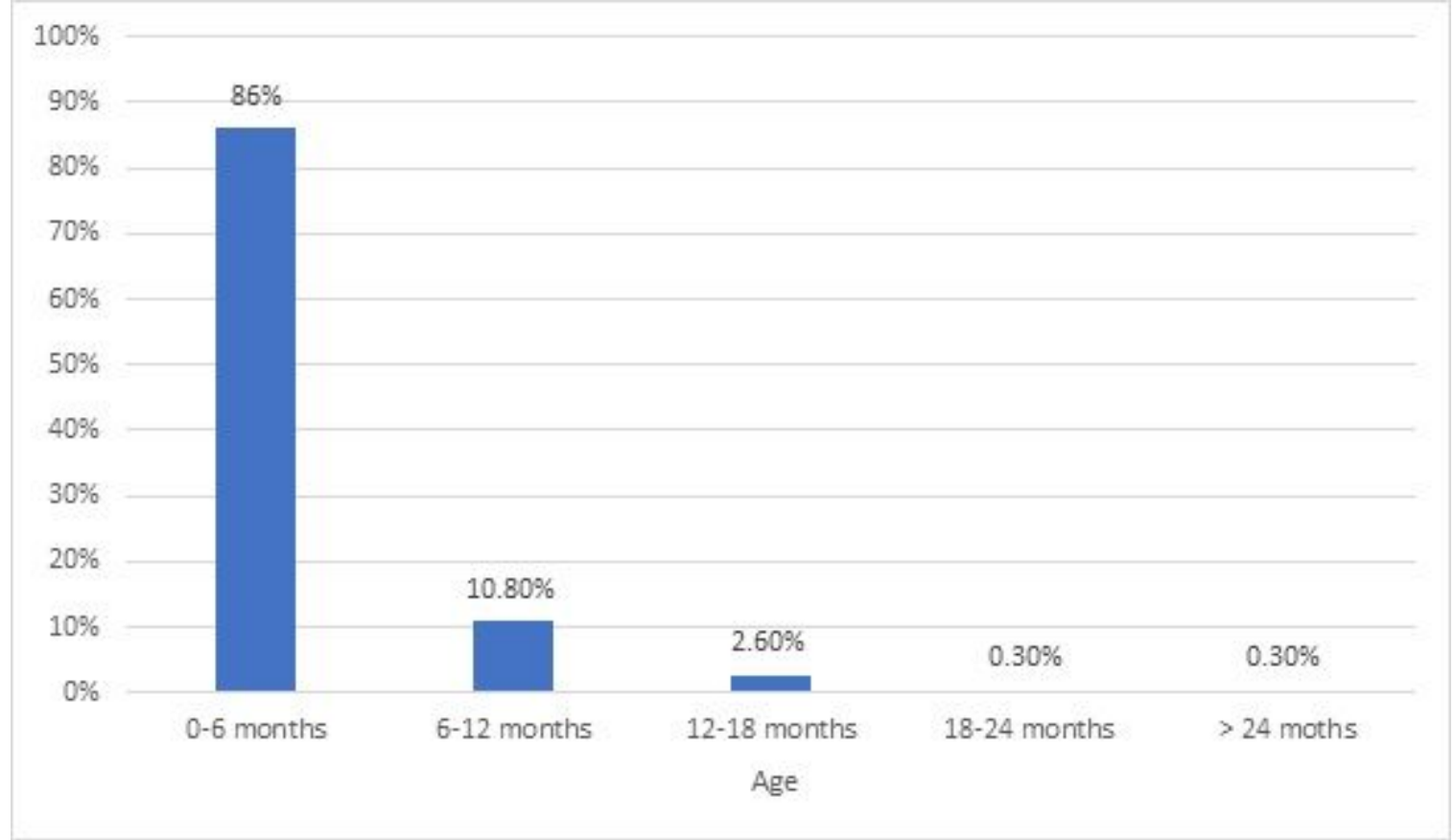

Figure 2

Age distribution of infants. 


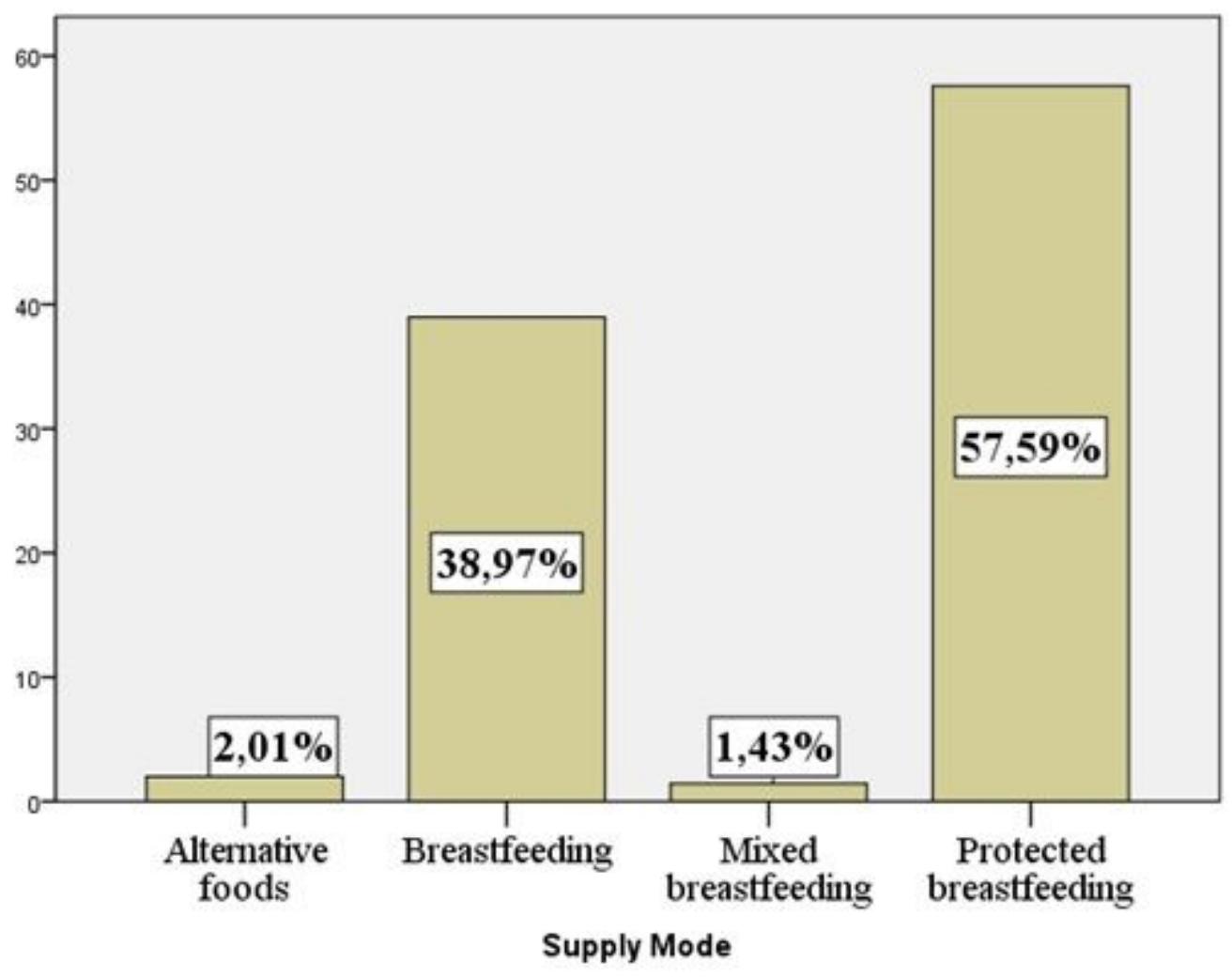

Figure 3

Distribution of children by supply mode

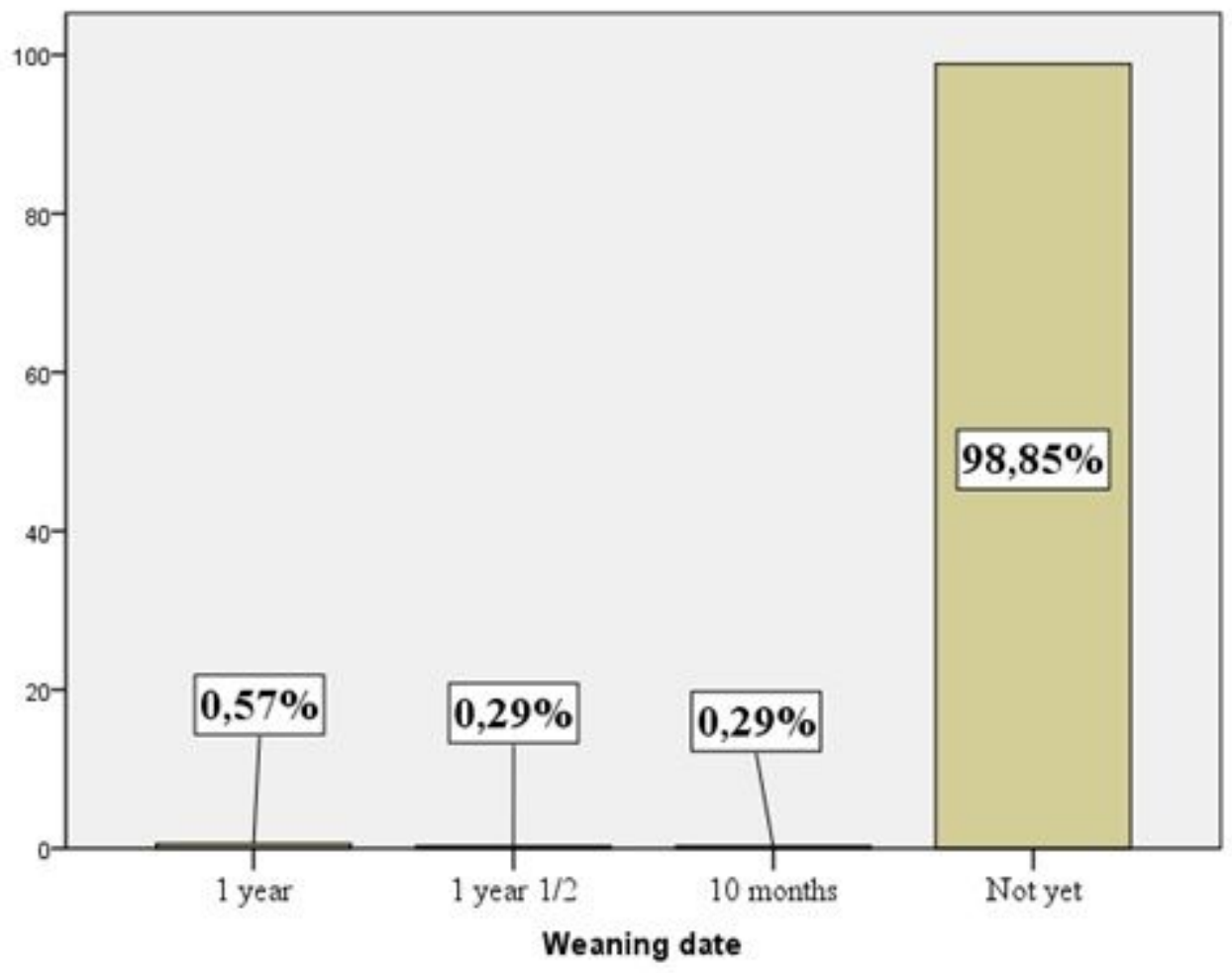


Figure 4

Distribution of Children by Weaning Date

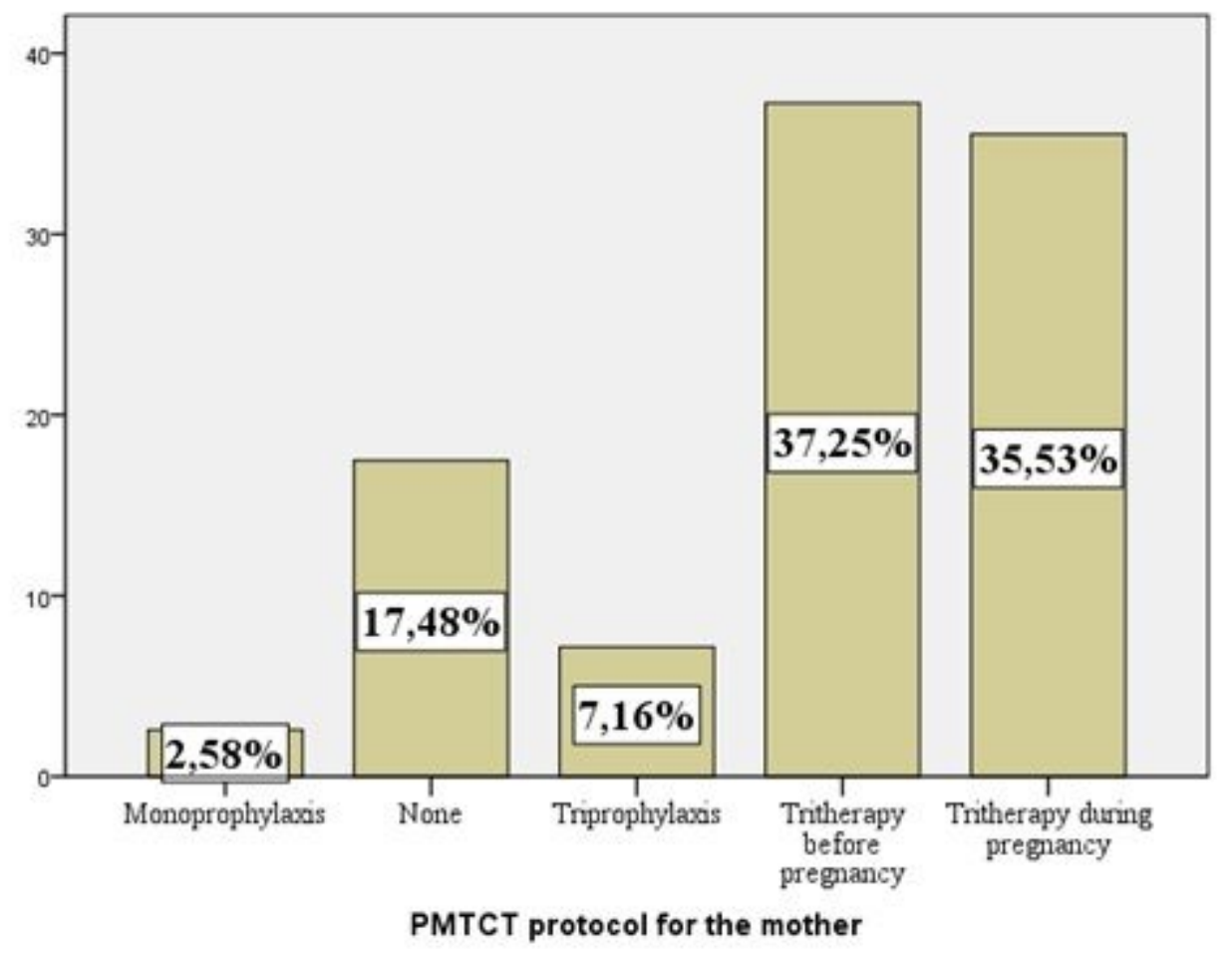

Figure 5

PMTCT protocol for mothers 


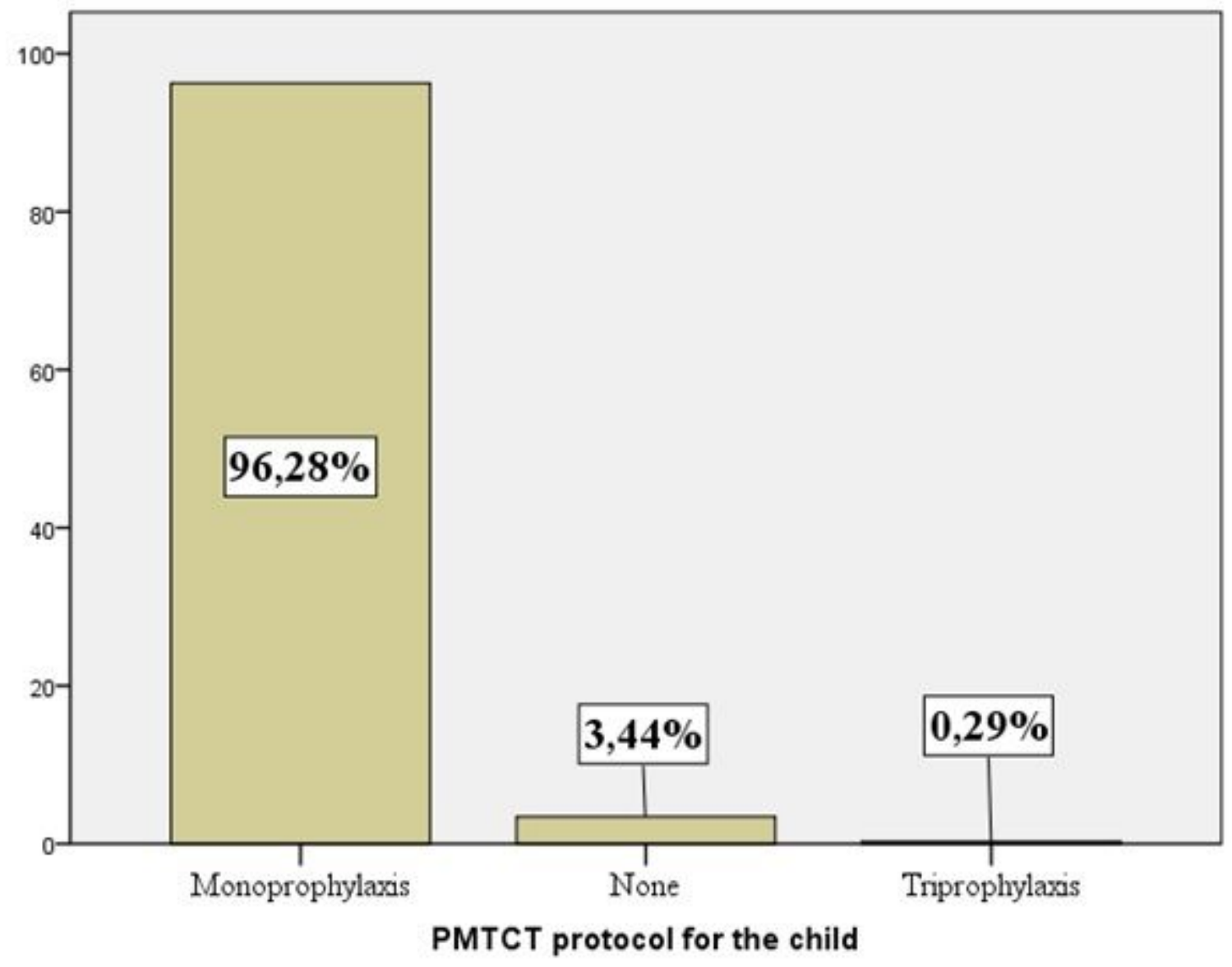

Figure 6

PMTCT protocol for infants 


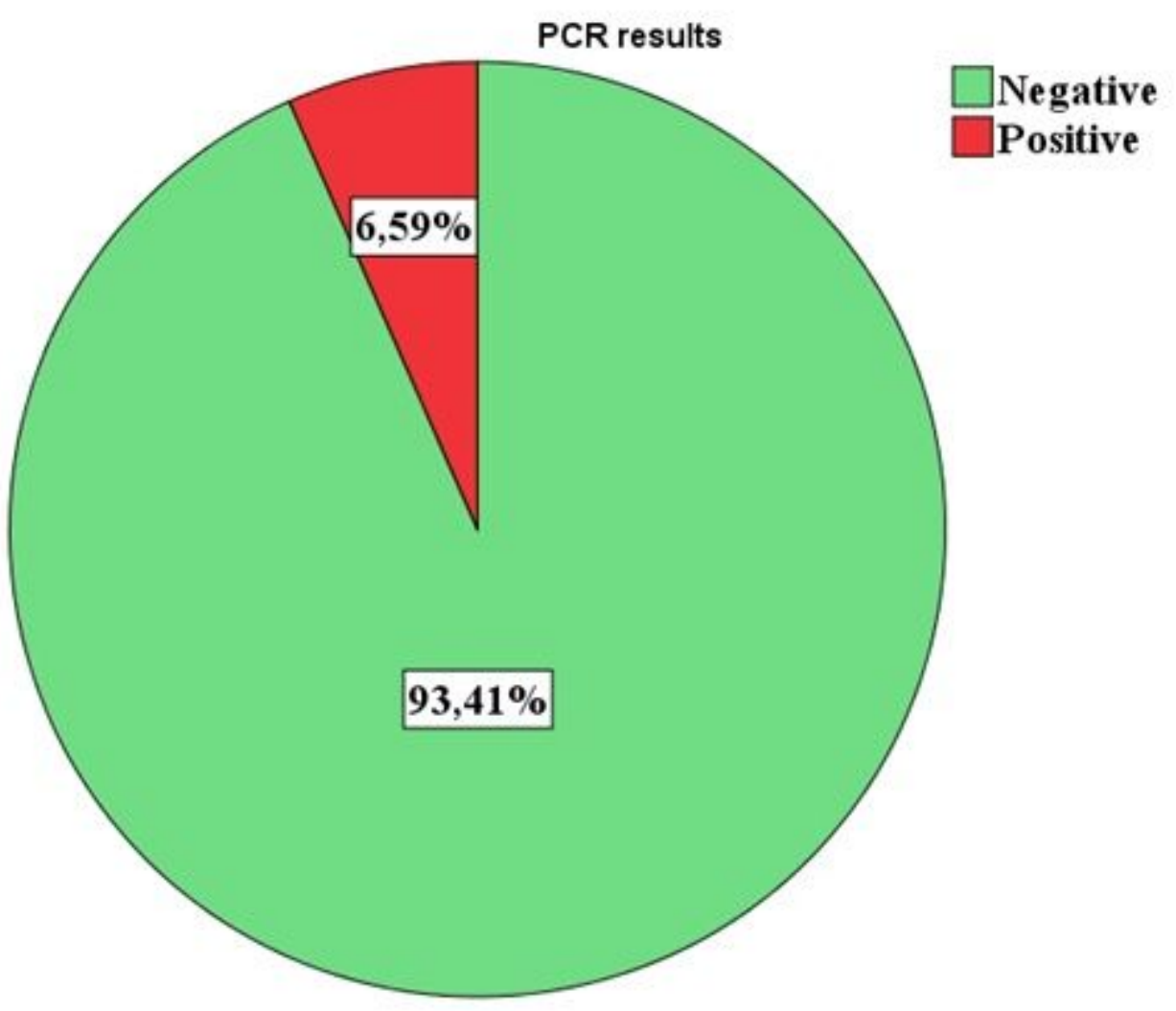

Figure 7

PCR Results for Newborns 